\title{
Klasszikus vérnyomáscsökkentők: diuretikumok
}

\author{
Nagy Viktor László dr. \\ Semmelweis Egyetem, Általános Orvostudományi Kar, II. Belgyógyászati Klinika, Budapest
}

\begin{abstract}
A diuretikumok a vérnyomáscsökkentő kezelés alapvető gyógyszerei. Kedvezően csökkentik a vérnyomást és a cardiovascularis eseményeket. A tiazidok és tiazidanalógok dózisának növelése nem eredményez további erőteljes vérnyomáscsökkenést és cardiovascularis morbiditás- és mortalitáscsökkenést. A dózisnövelés azonban a mellékhatásokat egyértelműen megemeli. Emiatt a legkisebb hatékony dózis adását kell előtérbe helyezni, valamint a fix kombinációs kezelést. Hypertoniában alkalmazásuk különösen kedvező eredményhez vezet időskorban, izolált szisztolés hypertoniában, szívelégtelenségben, korábban elszenvedett szélütésben és fekete bőrű populációban. Kacsdiuretikumok adása vérnyomáscsökkentőként csak beszúkült vesefunkció esetén jöhet szóba. Az aldoszteronantagonisták adása pedig szívelégtelenségben és pitvarfibrilláció prevenciójára különösen előnyös lehet, valamint kombinációs kezelés során csökkentik a hypokalaemia veszélyét. A hypertoniában alkalmazott diuretikus, valamint thiaziaddal való kombinációs kezelés ezért manapság a reneszánszát éli. Orv. Hetil., 2017, 158(11), 403-408.
\end{abstract}

Kulcsszavak: hypertonia, gyógyszeres kezelés, tiazid, tiazidanalóg, kacsdiuretikum, mineralokortikoidreceptor-antagonista

\section{Classical antihypertensive drugs: diuretics}

The diuretics are essential medicaments of antihypertensive therapy. They reduce blood pressure and cardiovascular events optimally. With increasing doses of thiazides and thiazide analogs do not come further powerful effect of reducing blood pressure or cardiovascular mortality and morbidity, but clearly elevate the side effects. Because of it, the minimum effective dose level and the fixed-dose combination therapy should be preferred. The use these drugs leads to especially positive outcome in elder patients, isolated systolic hypertension, heart failure, after stroke and in black population. Loop diuretics as antihypertensive therapy can be used only by renal impairment. The use of aldosterone antagonists can have a good effect not only on heart failure but also on prevention of atrial fibrillation. Furthermore, using it in a combination therapy with thiazides, it reduces the risk of hypokalemia. Therefore, the diuretic treatment in hypertension is flourishing again.

Keywords: hypertension, drug treatment, thiazid, thiazid analog, loop diuretic, mineralocorticoid receptor antagonist

Nagy, V. L. [Classical antihypertensive drugs: diuretics]. Orv. Hetil., 2017, 158(11), 403-408.

(Beérkezett: 2017. január 11.; elfogadva: 2017. január 26.)

\section{Rövidítések}

$\mathrm{ABPM}=$ (ambulatory blood pressure monitoring) ambuláns vérnyomás-monitorozás; ACE-i = angiotenzinkonvertálóenzimgátló; $\mathrm{ARB}=$ angiotenzinreceptor-blokkoló; $\mathrm{BBL}=$ béta-receptor-blokkoló; $\mathrm{CaA}=$ kalciumantagonista; $\mathrm{DBP}=$ diasztolés vérnyomás; HCTZ = hydrochlorotiazid; Hgmm = higanymilliméter; HYVET $=$ Hypertension in the Very Elderly Trial; NICE $=$ National Institute for Health and Care Excellence; PATHWAY = Prevention And Treatment of Hypertension With Algorithm-based therapY; SBP = szisztolés vérnyomás
Hajdan volt híres ókori s középkori személyiségek porhüvelyében sokszor azonosítanak különféle mérgeket (arzént, higanyt, ólmot), s máris ott a detektívtörténet alapja, ezt az uralkodót, azt a múvészt bizony meggyilkolta környezete. Pedig ha a középkor - s olykor napjaink - orvostudományára gondolunk, talán csupán gyógyszert kapott a szerencsétlen, mennél híresebb volt, esetleg annál többet. Higanyvegyületeket húgyhajtásra természetesen már Paracelsus is használt, de modern 
gyógyszerként a higanyos vízhajtókat az 1920-30-as évektől, a tiazidokat pedig az 1950-es évek végétől alkalmazzák az orvosok. Bár a diuretikumok számos kórkép kezelésére alkalmasak, jelen rövid összefoglalóban elsősorban a tiazidok és tiazidanalógok vérnyomáscsökkentésben betöltött szerepéről lesz szó.

\section{Felosztás}

Higanyos diuretikumokat már nem használunk, az ozmotikus diuretikumok és a szénsavanhidráz-bénítók igen szúk indikációs területébe pedig nem tartozik bele a hypertonia. Az enyhe diuretikumok közül sajnos már csak hármat forgalmaznak Magyarországon, a hydrochlorotiazidot (HCTZ) és két tiazidanalógot: a clopamidot és az indapamidot. A chlorthalidont pár éve teljesen érthetetlen okból kivonták a forgalomból. Két nagy hatású diuretikum áll rendelkezésre: furosemid, etachrinsav. A káliumspórolók között találunk két mineralokortikoidreceptor-antagonistát (spironolacton, eplerenon) és az amiloridot (kombinációs készítmény formájában, amely ismét csak érthetetlenül, nagy dózisú HCTZ-t és kis dózisú amiloridot tartalmaz). A szintén káliumspóroló triamterent nem forgalmazzák hazánkban. Az egyes csoportok hatásának helyét a nephronban az 1. ábra tartalmazza [1].

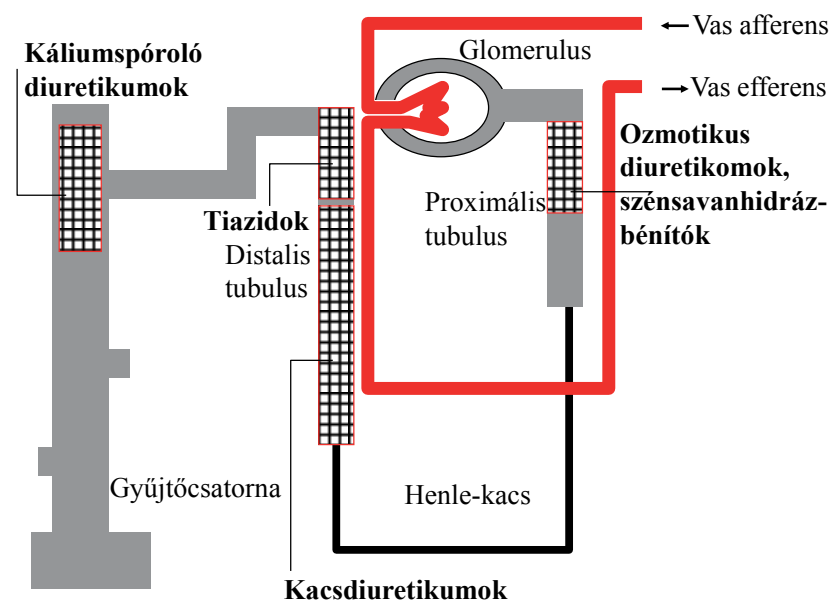

1. ábra

A diuretikumok hatásának helye a nephronban. A Henle-kacs felszálló vastag szegmensében, a $\mathrm{Na}^{+} / \mathrm{K}^{+} / 2 \mathrm{Cl}^{-}$kotranszporter segítségével reabszorbeálódik a $\mathrm{Na}^{+}$, ez a kacsdiuretikumok hatásterülete. A distalis kanyarulatos csatornában a tiazidokkal gátolható $\mathrm{Na}^{+} / \mathrm{Cl}^{-}$kotranszporterrel történik a $\mathrm{Na}^{+}$-reabszorpció. Végül a gyújtőcsatornákban a $\mathrm{Na}^{+}$-csatornákon folyik a $\mathrm{Na}^{+}$-visszaszívás, amely pedig a káliumspóroló diuretikumokkal gátlódik [1]

\section{Hatásmechanizmus}

Az eltérő csoportok eltérő hatásmechanizmussal bírnak, de a húgyhajtás elvileg nagyon egyszerúen magyarázható: a nephron különböző szakaszainak funkcióját gátolják úgy, hogy ennek eredményeként erőteljesen megnő a vizelet mennyisége.
- A tiazidok és tiazidanalógok a distalis tubulus Henlekacshoz közeli kezdeti szakaszán (ahol a filtrált nátrium csupán 3-5\%-a ürül), gátolják a $\mathrm{Na}^{+} / \mathrm{Cl}^{-}$kotranszportert, ezért a nátrium, klór, víz kiválasztása fokozódik. A diuretikus hatás csökkenti a plazmavolument, ezért növeli a plazmarenin-aktivitást és növeli az aldoszteron elválasztását, ami következésképpen emeli a vizelettel történő kálium- és bikarbonátkiválasztást és csökkenti a szérumkáliumszintet. Mindhárom forgalmazott diuretikum tartalmaz szulfonamidcsoportot, emiatt igen gyenge karboanhidráz-bénító hatás is felismerhető, jelentős mértékű vizelet-pH-változás nélkül. Kismértékben megnő a magnéziumkiválasztás, viszont fokozódik a kalciumreabszorpció. A vérnyomás- és elektrolitváltozások nagysága dózistól és hatóanyagtól függ [1].

- A kacsdiuretikumok a Henle-kacs felszálló vastag szegmentumában gátolják a $\mathrm{Na}^{+} / \mathrm{K}^{+} / 2 \mathrm{Cl}^{-}$kotranszportert. Emiatt a nátrium- és kloridionok reabszorpciójának gátlásával alacsony glomerulusfiltráció esetén (például krónikus veseelégtelenségben) is rendkívül hatékonyan növeli meg a vizelet mennyiségét. Erőteljesen gátolja a kálium reabszorpcióját, és fokozza a kalcium és a magnézium kiválasztását is [1].

- A spironolacton és a nagyobb szelektivitással rendelkező eplerenon a vese distalis tubulusaiban a mineralokortikoidreceptorokon gátolja az aldoszteron hatását, emiatt megnő a vizelet nátrium- és kloridkoncentrációja, a káliumkiválasztás és a vizeletbe történő $\mathrm{H}^{+}$-kiválasztás pedig gátlódik [1].

- Az amilorid a distalis tubulusok és gyüjtőcsatornák epithelialis nátriumcsatornáinak direkt bénításával meggátolja a kálium és a hidrogén szekrécióját, és növeli a vizelet nátrium-, klorid-, bikarbonátkoncentrációját és a vízkiválasztást [1].

A vizhajtók vérnyomáscsökkentó hatásmechanizmusa részben a húgyhajtó hatással megmagyarázható, hiszen a natriuresis és a diuresis fokozásával csökken az intravasalis és extracellularis folyadéktérfogat. Feltételezhető, hogy eközben mérséklődik az arteriolák falának oedemája és nátriumtartalma. Végül négy-nyolc hét elteltével csökken a teljes vascularis rezisztencia, és eközben normalizálódik a verővolumen. A vízhajtók vérnyomáscsökkentő mechanizmusában tehát két komponens észlelhető, kezdetben a nátrium- és vízürítés dominál, majd később változatlanul alacsonyabb extracelluláris folyadéktérfogat és normalizálódó tendenciájú plazmavolumen mellett csökken a teljes vascularis rezisztencia. A gyógyszercsoport emellett változó mértékben cardiovascularis remodellinggátló, endothelfunkciót javító, oxidatív stresszt csökkentő hatást is kifejt [2-6].

A húgyhajtás okozta hypovolaemia ellenregulációs mechanizmusokat provokál $[1,3,7]$ :

- a renin-angiotenzin-aldoszteron rendszer aktiválódását (vasoconstrictio, nátriumretenció) és

- a sympathoadrenerg rendszer aktiválódását (tachycardia). 
1. táblázat | Egyes vízhajtók farmakokinetikai adatai. A nagy tanulmányok alapján a viszonylag rövidebb hatástartamú HCTZ lassú kioldódású formáit elegendő naponta egyszer adni [8]

\begin{tabular}{lllll}
\hline & HCTZ & $\begin{array}{l}\text { Indapamid } \\
\text { (elnyújtott kioldódás })\end{array}$ & Furosemid & $\begin{array}{l}\text { Spironolacton } \\
\text { canrenon })\end{array}$ \\
\hline Felszívódás & Teljes & Teljes & $60-70 \%$ & $73 \%$ \\
\hline Csúcskoncentráció & $4-6 \mathrm{~h}$ & $12 \mathrm{~h}$ & $\mathrm{~Kb} .1 \mathrm{~h}$ & $\mathrm{l}-2 \mathrm{~h}(3 \mathrm{~h})$ \\
\hline Plazmafelezési idő & $10-12 \mathrm{~h}$ & $14-24 \mathrm{~h}$ & $\mathrm{l}$ & $\mathrm{l}-2 \mathrm{~h}(18-23 \mathrm{~h})$ \\
\hline Metabolizmus & Nincs & Máj, kb. 5\% nem & Máj 10\% & Máj/vese \\
\hline Ürülés & Vizelet & $\begin{array}{l}\text { Széklet kb. 22\%, } \\
\text { vizelet kb. 70\% }\end{array}$ & $\begin{array}{l}\text { Elsósorban vizelet, } \\
\text { kevésbé széklet }\end{array}$ \\
\hline
\end{tabular}

2. táblázat $\mid$ Különféle dózisú tiazidok és tiazidanalógok szisztolés vérnyomást csökkentő hatása a placebóhoz képest $[9,10]$

\begin{tabular}{llc}
\hline Diuretikum & Dózis & $\begin{array}{c}\text { Szisztolés vérnyomáscsökkenés } \\
\text { a placebóhoz képest }\end{array}$ \\
\hline Hydrochlorotiazid & $6,25 \mathrm{mg}$ & $3,08 \mathrm{Hgmm}$ \\
& $12,5 \mathrm{mg}$ & $6,42 \mathrm{Hgmm}$ \\
& $25 \mathrm{mg}$ & $11,13 \mathrm{Hgmm}$ \\
& $50 \mathrm{mg}$ & $10,6 \mathrm{Hgmm}$ \\
& $100 \mathrm{mg}$ & $10,3 \mathrm{Hgmm}$ \\
\hline Chlorthalidon & $12,5 \mathrm{mg}$ & $10,61 \mathrm{Hgmm}$ \\
& $25 \mathrm{mg}$ & $13,85 \mathrm{Hgmm}$ \\
& $50 \mathrm{mg}$ & $16,01 \mathrm{Hgmm}$ \\
& $75 \mathrm{mg}$ & $14,1 \mathrm{Hgmm}$ \\
\hline Indapamid & $1,25 \mathrm{mg} \mathrm{SR}$ & $6,5 \mathrm{Hgmm}$ \\
& $1,5 \mathrm{mg} \mathrm{SR}$ & $6,91 \mathrm{Hgmm}$ \\
& $2,5 \mathrm{mg}$ & $6,87 \mathrm{Hgmm}$ \\
\hline
\end{tabular}

Az ellenreguláció kissé mérsékli a vérnyomás csökkenését, ugyanakkor felismerésével könnyedén értelmezhetôvé válik egy renin-angiotenzin-aldoszteron rendszert gátló szerrel vagy béta-receptor-blokkolóval történő kombinációs kezelés a mindennapi gyakorlatban észlelt nagyon kedvező hatása.

A fóbb diuretikumok farmakokinetikai tulajdonságait tartalmazza az 1. táblázat [8].

\section{Vérnyomáscsökkentés nagysága a tanulmányok alapján}

Számos tanulmányban vizsgálták a tiazidok és tiazidanalógok vérnyomáscsökkentő hatását. A végeredmény szempontjából a cardiovascularis eseményeket feldolgozó tanulmányok érdekes módon alig vehetők figyelembe, mert dózisváltoztatásra nyílt bennük lehetőség. A randomizált tanulmányokban a placebokezeléshez képest a fix tiazid- és tiazidanalóg-dózisok mellett elért szisztolésvérnyomás-csökkenéseket (aktív mínusz placebokezelés) tartalmazza a 2. táblázat $[9,10]$. Az eredmények azt sugallják, hogy a nagyobb dózistartományok- ban nem nő tovább egyik diuretikum vérnyomáscsökkentő ereje sem, tehát a dózis-hatás görbe ellapul, viszont a dózis-mellékhatás görbe erôteljesen megemelkedik. Ezért a kezelés során sosem a tolerált maximális, hanem a már elegendően hatékony minimális dózis elérése a cél.

Mindenképpen ki kell térni a HYVET tanulmány eredményeire, hiszen a placebóhoz képest az indapamid átlagosan 15/6 Hgmm-rel alacsonyabb vérnyomást eredményezett. A tanulmány során azonban, a vizsgálatot végzők döntése alapján, további vérnyomáscsökkentés érdekében perindoprillal lehetett bővíteni a kezelést, ezért a jelentős mértékű vérnyomáskülönbséget a 2. táblázat összeállításakor nem lehetett figyelembe venni [11].

Egy kutatásban összehasonlították kétféle diuretikum vérnyomáscsökkentő hatékonyságát, és az indapamid a HCTZ-nél 5,1 Hgmm-rel nagyobb szisztolésvérnyomás-csökkentést eredményezett $(813$ beteg, 11 tanulmány, időtartam 2-26 hét, átlagosan 10,5 hét, dózisegyezés: 4, relatíve nagyobb HCTZ-dózis: 5, relatíve nagyobb indapamiddózis: 2 tanulmány, $\mathrm{p}=0,004)$. A vizsgált vérparaméterek változásában (kálium, nátrium, kreatinin, cukor, koleszterin, húgysav) a két kezelési csoport között nem találtak szignifikáns különbséget. A chlorthalidon 3,6 Hgmm-rel erösebben csökkentette a szisztolés vérnyomást, mint a HCTZ (3 tanulmány, 70 beteg, minden esetben dózisegyezés, $\mathrm{p}=0,052)$ [12].

A korai vizsgálatok a clopamid oedema- és vérnyomáscsökkentő hatását tárták fel. Egy kis tanulmányban 19 beteg vérnyomását 169/91 Hgmm-ról 157/88 Hgmmre csökkentette a clopamid ( 5 napig 20 , majd 25 napig $10 \mathrm{mg}$ szedése mellett) [13].

A gyógyszerválasztásban fontos szempont az egyenletes, 24 órára kiterjedő vérnyomáscsökkentés biztosítása. Egy kutatásba olyan tanulmányokat választottak be, amelyek ABPM során hasonlították össze a különféle dózisú HCTZ hatását más vérnyomáscsökkentőkkel (19 tanulmány 12,5-25 mg HCTZ, 5 tanulmány $50 \mathrm{mg}$ HCTZ, kontroll: konvencionális dózisú ACE-gátlók, ARB-k, BBL-k, CaA-k). A 2. ábra tartalmazza azt, hogy a nagy dózisú HCTZ és a többi szer vérnyomáscsökkentő hatása egymástól nem tért el, de szignifikáns mértékben kisebb volt a $12,5 \mathrm{mg}$ és a $25 \mathrm{mg}$ HCTZ hatása [14]. 


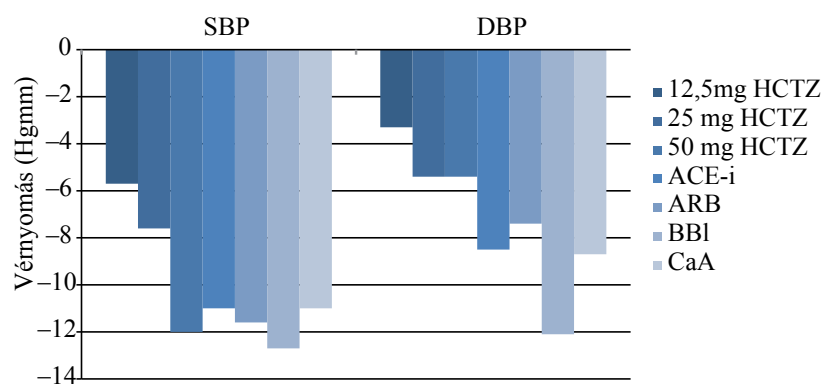

2. ábra

Különböző dózisú HCTZ- és ACE-gátló, ARB-, BBL-, CaAkezelés eredményezte - ABPM-mel regisztrált - vérnyomáscsökkenés [14]

ACE- $\mathrm{i}=$ angiotenzinkonvertálóenzim-gátló; $\mathrm{ARB}=$ angioten zinreceptor-blokkoló; $\mathrm{BBL}=$ béta-receptor-blokkoló; $\mathrm{CaA}=$ kalciumantagonista; $\mathrm{DBP}=$ diasztolés vérnyomás; $\mathrm{SBP}=$ szisztolés vérnyomás

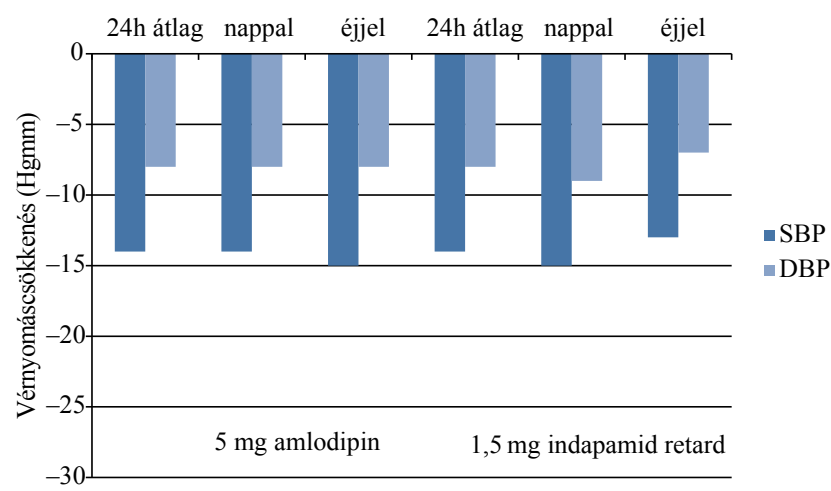

3. ábra

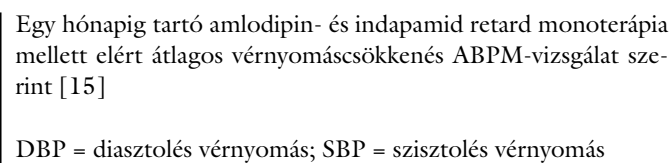

Egy tanulmányban a tiazidanalóg $1 \times 1,5 \mathrm{mg}$ indapamid retard és a CaA $1 \times 5 \mathrm{mg}$ amlodipin vérnyomáscsökkentő hatását vizsgálták meg és elvégezték az ABPM-et is. A két hatóanyag 24 órás, nappali és éjszakai vérnyomáscsökkentő hatása nem tért el egymástól szignifikáns mértékben, és mindkét kezelés során megmaradt a vérnyomás dipper diurnalis ritmusa is, ahogyan azt a 3. ábra bemutatja [15].

\section{Tiazidok és tiazidanalógok hatása a cardiovascularis eseményekre}

A brit NICE-ajánlásban szigorú beválasztási kritériumok szerint 12 valóban minőségi vizsgálatot elemeztek. A korai (1960-as évek elején elkezdett) tanulmányokban nagy dózisú tiazidok és tiazidanalógok szerepeltek (7 tanulmány, 19933 beteg, átlagéletkor 51 év, 53\% férfi, követési idő átlagosan négy év). A nagy dózis fogalmát nehéz meghatározni, de annak tartható, ha a vizsgálat kezdetekor a chlorthalidon és a HCTZ dózisa is $\geq 50 \mathrm{mg}$. Ilyen nagy dózisokat az előtérbe kerülő mellékhatások miatt manapság már nem alkalmazunk. 1975-1989 között el- sősorban kis dózisú (csak a tanulmány végére lehetett elérni a maximális $50 \mathrm{mg}$-ot) vízhajtókat teszteltek (öt tanulmány, 15086 beteg, átlagéletkor 67 év, 53\% férfi, átlagos követési idő négy év). A nagy dózisú tanulmányokban nem csökkent szignifikáns mértékben az összmortalitás és a halálos/nem halálos szívinfarktus kockázata. A kis dózisú tanulmányokban szignifikáns mértékben, 9\%-kal csökkent az összmortalitás, 22\%-kal a szívinfarktus és 31\%-kal a szélütés kockázata [16]. Más metaanalízisek is hasonló eredményre jutottak $[17,18]$.

Ezek után, ha összevetjük a kis dózisok vérnyomáscsökkentő, cardiovascularis eseményt csökkentő, valamint mellékhatásokat provokáló hatását, akkor kiderül, hogy a HCTZ kisebb dózisa kedvezően csökkenti a cardiovascularis eseményeket, beleértve a mortalitást is, kevés mellékhatást okoz, de a vérnyomást csökkentő hatása kisebb, mint az indapamidé vagy a chlorthalidoné. Utóbbinak viszont kis dózisa is relatíve sok mellékhatást okoz, és éppen nincs is forgalomban Magyarországon. A clopamiddal kapcsolatosan a vérnyomáscsökkentésen kívüli evidencia nincs. A legkedvezőbb hatásprofillal és legkevesebb mellékhatással a lassú kioldódású, 1,5mgos indapamid rendelkezik [16].

\section{Egyéb diuretikumok hatása a vérnyomásra és a cardiovascularis eseményekre}

A kacsdiuretikumok inkább húgyhajtók, mint vérnyomáscsökkentők. Vérnyomáscsökkentőként a furosemid naponta kétszer adható $250 \mu \mathrm{mol} / 1$ szérumkreatininszint felett, mivel a tiazidok ekkor már hatástalanok, az aldoszteronantagonisták pedig kontraindikáltak [1].

$\mathrm{Az}$ aldoszteronreceptor-antagonisták diuretikus és vérnyomáscsökkentő hatása önmagukban gyenge, de hyperaldosteronismus esetén áttörhetik a terápiarezisztenciát. Szívelégtelenségben, szívinfarktus után számos kedvező hatásuk igazolódott, javítják az életminőséget, csökkentik a mortalitást. Gátolják a fibrosist, csökkentik a balkamra-hypertrophiát, szív-ér rendszeri remodellációt [19].

Egy vizsgálatsorozatban (PATHWAY2-3)

- a spironolactont hatékonyabbnak találták a terápiarezisztens hypertonia kezelésére, mint a BBL bisoprolol és alfa-receptor-blokkoló doxazosin kezelést [20];

- amiloridból (káliumspóroló diuretikum) + HCTZ-ből álló kombinációval a célvérnyomás könnyebben volt elérhető és kevesebb volt a mellékhatás (plazmaglükóz-emelkedés étkezés után két órával, káliumszintcsökkenés), mint a két összetevővel végzett monoterápia során külön-külön [21].

\section{Mellékhatások}

A mellékhatások többsége hosszabb idő alatt és nagyobb dózisok mellett válik gyakoribbá és súlyosabbá. A tiazi- 
dok egyéni érzékenységtől függően, eltérő mértékben, leggyakrabban különféle elektrolitzavart okoznak: hypokalaemia, hyponatraemia, hypochloraemia, hypomagnesaemia, hypercalcaemia, továbbá hyperurikaemia, toxikus bőrkiütések, fényérzékenység, impotencia, ritkán pancreatitis léphet fel, romlik a szénhidrát- és lipidanyagcsere.

A kacsdiuretikumok mellékhatásprofilja hasonló, de hypercalcaemia helyett éppen csökkentik a kalciumszintet és dehidrációt, hypovolaemiát, csontvelő-károsítást, hallásromlást is okozhatnak.

A hypokalaemia egyértelmúen nagyobb dózisok mellett válik súlyosabbá. Következményei: szívritmuszavar, hirtelen halál, inzulinérzékenység romlása (diabetogén hatás), izomgyengeség. A hypokalaemia veszélye az étrend átalakításával csökkenthető: konyhasófogyasztás csökkentése, káliumtartalmú ételek-italok (gyümölcsök, természetes gyümölcslevek) fogyasztása. A kombinációs kezelések gyakorisága manapság erőteljesen növekszik, és a káliumspóroló diuretikumok, renin-angiotenzin-aldoszteron rendszer gátlószerei, BBL-k csökkentik a hypokalaemia fellépésének kockázatát, illetve súlyosságát. Mindenesetre a rutinszerü káliumpótlás kerülendő, káliumadásra csak hypokalaemia igazolása esetén kerüljön sor.

Hyponatraemia általában a fölöslegesen nagy dózisok mellett lép fel, ugyanakkor aldoszteronreceptor-blokkolókkal együtt adva, nyáron nagy melegben, gastroenteritisek során, inkább idősekben és nőkben gyakoribb. Alvászavarral gyakran jár együtt.

Tiazidok és tiazidanalógok adása során fokozódik a renalis kalcium-visszaszívás, amelynek végül hypercalcaemia lesz az eredménye. Erre mindig gondolni kell osteoporosis, D-vitamin-kezelés vagy éppen hyperparathyreoidismus észlelésekor. A csontokban kalciumretenció jön létre, ez pedig védhet az osteoporosistól és törésektől [22].

A kis dózisú tiazidkezelés időszakában a számottevő dyslipidaemia és vércukor-emelkedés fellépésének valószínűsége kicsi, a kezelés elhagyása után pedig normalizálódnak a provokált anyagcsere-rendellenességek. Különböző kutatások igazolták azt, hogy a kis dózisú tiazidok és tiazidanalógok kisebb anyagcserehatást provokálnak, mint a nagy dózisok, az éhomi vércukorszintet pedig legkevésbé az indapamid emeli [10,23].

Erectilis diszfunkció gyakrabban fordul elő diuretikumok, mint más vérnyomáscsökkentők használata mellett, és az esetlegesen meglevő panaszokat egyértelműen súlyosbítja.

A káliumspóroló diuretikumok már enyhe vesekárosodásban is csak óvatosan, kisebb dózisok mellett adhatók. A szérumkáliumszintet $4,5 \mathrm{mmol} / 1$ felett gyakrabban kell ellenőrizni. Káliumkiegészítők általánosságban nem használhatók. Az aldoszteronreceptor-blokkolók gyakran csökkentik a libidót, okoznak erectilis diszfunkciót, mellfeszülést (férfiakban gynecomastiát), menstruációs zavarokat [24].

\section{Ajánlások}

Nagy várakozás előzte meg az európai hypertoniaajánlás frissítését, amely 2013-ban történt meg [25]. A dokumentum szerint a vízhajtók a vérnyomáscsökkentő kezelés alapszerei közé tartoznak. A várttal ellentétben a szakértők nem helyezték előtérbe egyik szert sem (pedig a chlorthalidon és indapamid a metaanalízisek szerint erőteljesebb vérnyomáscsökkenést eredményez, mint a HCTZ). Nem mondták ki a kevesebb mellékhatással járó kis dózisú HCTZ-kezelés egyértelmú hasznosságát sem. Amennyiben viszont nem érhető el monoterápiával a célvérnyomás, nem a mellékhatásokkal járó dózisemelést, hanem a gyógyszer-kombinációk alkalmazását javasolták. Azonnali gyógyszer-kombináció pedig magasabb kiindulási vérnyomás, nagyobb cardiovascularis kockázat és várhatóan rosszabb együttmúködési hajlam esetén ajánlott. Az anyagcsere-mellékhatások csökkentése szempontjából különösen fontos a tiazidok és tiazidanalógok ACE-gátlókkal, illetve ARB-kel való kombinálása. Kiemeltek a hypertoniához társuló speciális indikációs területeket, amelyekben a tiazidok és tiazidanalógok a többinél kedvezőbb kimenetelt eredményezhetnek: szívelégtelenség, korábban elszenvedett szélütés, izolált szisztolés hypertonia, időskor, fekete bőrszínú populáció. Az aldoszteronantagonisták adása pedig szívelégtelenségben és pitvarfibrilláció prevenciójára különösen előnyös lehet [25].

\section{Következtetés}

A diuretikumok a vérnyomáscsökkentő terápia első vonalbeli szerei amióta hypertoniaajánlást készítenek a szakértők. Természetesen nem nélkülözhetők más kardiológiai kórképek, elsősorban a szívelégtelenség kezelésére sem. Különösen fontos adásuk terápiarezisztens hypertoniában és időskor esetén. A tiazid-tiazidanalóg monoterápia cardiovascularis eseményeket csökkentő hatását még egyetlen tanulmányban sem múlta felül a kontrollvegyület, de fix kombinációs kezelések összehasonlítása során már volt erre példa [25]. Dózisemelés a mellékhatások számának növekedésével jár együtt, és eközben nem javul megfelelően a vérnyomáscsökkentés ereje. Emiatt a minimálisan hatékony dózis és a kombinációs kezelés fontosságát kell hangsúlyozni.

Anyagi támogatás: A közlemény megírása anyagi támogatásban nem részesült.

A cikk végleges változatát a szerző elolvasta és jóváhagyta.

Érdekeltségek: Nagy Viktor László dr. korábban (>10 év) részt vett indapamidgyógyszer-tanulmányban és előadói, publikációs, valamint utazási támogatást kapott a Servier gyógyszercégtől. A közzétett dolgozat megállapításai ismert tényeken alapulnak, széles körben csak részben terjedtek el. 


\section{Irodalom}

[1] Kecskeméti, V.: Diuretics. In: Fürst, Zs. (ed.): Pharmacology. [Diuretikumok (húgyhajtók). In: Fürst, Zs. (szerk.): Farmakológia.] Medicina Könyvkiadó, Budapest, 2001, 571-587. [Hungarian]

[2] Van Brummelen, P., Man in 't Veld, A. J., Schalekamp, M. A. Hemodynamic changes during long-term tiazide treatment of essential hypertension in responders and nonresponders. Clin. Pharmacol. Ther., 1980, 27(3), 328-336.

[3] Tarazi, R. C., Dustan, H. P., Frohlich, E. D.: Long-term tiazide therapy in essential hypertension. Evidence for persistent alteration in plasma volume and renin activity. Circulation, 1970, 41(4), 709-717.

[4] Shabin, M. H., Johnson, J. A.: Mechanisms and pharmacogenetic signals underlying tiazide diuretics blood pressure response. Curr. Opin. Pharmacol., 2016, 27, 31-37.

[5] Woodman, R., Brown, C., Lockette, W.: Chlorthalidone decreases platelet aggregation and vascular permeability and promotes angiogenesis. Hypertension, 2010, 56(3), 463-470.

[6] Sato, K., Dohi, Y., Kojima, M., et al.: Antioxidative effects of tiazide diuretics in refractory hypertensive patients. A randomized crossover trial of chlortalidone and trichlormetiazide. Arzneimittelforschung, 2010, 60(10), 612-616.

[7] Lohmöller, G., Lohmöller, R., Pfeffer, M. A., et al.: Mechanism of immediate hemodynamic effects of chlorotiazide. Am. Heart J., $1975,89(4), 487-492$

[8] https://www.pharmindex-online.hu/termekek [accessed: January 6,2017 ]. [Hungarian]

[9] Peterzan, M. A., Hardy, R., Chaturvedi, N., et al.: Meta-analysis of dose-response relationships for hydrochlorotiazide, chlorthalidone, and bendroflumetiazide on blood pressure, serum potassium, and urate. Hypertension, 2012, 59(6), 1104-1109.

[10] Brodszky, V., Nagy, V., Farsang, C., et al.: The efficacy of indapamide in different cardiovascular outcome - meta-analysis. $\mathrm{Az}$ indapamid hatásosságának elemzése különböző cardiovascularis végpontok szerint - metaanalízis.] Orv Hetil., 2007, 148(26), 1203-1211. [Hungarian]

[11] Beckett, N. S., Peters, R., Fletcher, A. E., et al., for the HYVET Study Group: Treatment of hypertension in patients 80 years of age or older. N. Engl. J. Med., 2008, 358(18), 1887-1898.

[12] Roush, G. C., Ernst, M. E., Kostis, J. B., et al.: Head-to-head comparisons of hydrochlorotiazide with indapamide and chlorthalidone: antihypertensive and metabolic effects. Hypertension, 2015, 65(5), 1041-1046.

[13] Johansson, B. W.: Clopamide: a clinical study of a new oral diuretic. Angiology, 1968, 19(3), 161-168.

[14] Messerli, F. H., Makani, H., Benjo, A., et al.: Antihypertensive efficacy of hydrochlorotiazide as evaluated by ambulatory blood pressure monitoring: a meta-analysis of randomized trials. J. Am. Coll. Cardiol., 2011, 57(5), 590-600.

[15] Libhaber, E. N., Libhaber, C. D., Candy, G. P., et al.: Effect of slow-release indapamide and perindopril compared with amlodi- pine on 24-hour blood pressure and left ventricular mass in hypertensive patients of African ancestry. Am. J. Hypertens., 2004, 17(5 Pt 1), 428-432.

[16] Hypertension in adults: diagnosis and management. https:// www.nice.org.uk/guidance/CG127 [accessed: January, 6, 2017].

[17] Psaty, B. M., Lumley, T., Furberg, C. D., et al.: Health outcomes associated with various antihypertensive therapies used as firstline agents: a network meta-analysis. JAMA, 2003, 289(19), 2534-2544.

[18] Thomopoulos, C., Parati, G., Zanchetti, A.: Effects of blood pressure lowering on outcome incidence in hypertension: 4. Effects of various classes of antihypertensive drugs - overview and metaanalyses. J. Hypertens., 2015, 33(2), 195-211.

[19] Seferovic, P. M., Pelliccia, F., Zivkovic, I., et al.: Mineralocorticoid receptor antagonists, a class beyond spironolactone - Focus on the special pharmacologic properties of eplerenone. Int. J. Cardiol., 2015, 200, 3-7.

[20] Williams, B., MacDonald, T. M., Morant, S., et al., for the British Hypertension Society's PATHWAY Studies Group: Spironolactone versus placebo, bisoprolol, and doxazosin to determine the optimal treatment for drug-resistant hypertension (PATHWAY-2): a randomised, double-blind, crossover trial. Lancet, 2015, 386(10008), 2059-2068.

[21] Brown, M. J., Williams, B., Morant, S. V., et al., for the British Hypertension Society's Prevention and Treatment of Hypertension with Algorithm-based Therapy (PATHWAY) Studies Group: Effect of amiloride, or amiloride plus hydrochlorotiazide, versus hydrochlorotiazide on glucose tolerance and blood pressure (PATHWAY-3): a parallel-group, double-blind randomised phase 4 trial. Lancet Diabetes Endocrinol., 2016, 4(2), 136147.

[22] Solomon, D. H., Ruppert, K., Zhao, Z., et al.: Bone mineral density changes among women initiating blood pressure lowering drugs: a SWAN cohort study. Osteoporos. Int., 2016, 27(3), 1181-1189.

[23] Zhang, X., Zhao, Q.: Association of tiazide-type diuretics with glycemic changes in hypertensive patients: A systematic review and meta-analysis of randomized controlled clinical trials. J. Clin. Hypertens. (Greenwich), 2016, 18(4), 342-351.

[24] Roush, G. C., Ernst, M. E., Kostis, J. B., et al.: Dose doubling, relative potency, and dose equivalence of potassium-sparing diuretics affecting blood pressure and serum potassium: systematic review and meta-analyses. J. Hypertens., 2016, 34(1), 11-19.

[25] Mancia, G., Fagard, R., Narkiewicz, K., et al.: 2013 ESH/ESC guidelines for the management of arterial hypertension: the Task Force for the Management of Arterial Hypertension of the European Society of Hypertension (ESH) and of the European Society of Cardiology (ESC). Eur. Heart J., 2013, 34(28), 21592219.

(Nagy Viktor László dr., Budapest, Szentkirályi u. 46., 1088 e-mail: nagy.viktor@med.semmelweis-univ.hu)

Az Orvosi Hetilap egyes számai megvásárolhatók a Mediprint Orvosi Könyvesboltban. Cím: Budapest V., Múzeum krt. 17. - Telefon: 317-4948 